\title{
Seng dan Respons Imun pada Talasemia
}

Teny Tjitra Sari

Departemen Ilmu Kesehatan Anak Fakultas Kedokteran Universitas Indonesia/RS Dr. Cipto Mangunkusumo, Jakarta

Infeksi merupakan morbiditas dan mortalitas yang penting pada pasien talasemia. Mekanisme terjadinya infeksi yang berperan adalah gangguan respons imun akibat patofisiologi penyakit talasemia, kelebihan besi, splenektomi dan defisiensi seng. Seng merupakan zat penting pada respons imun yang dihubungkan dengan akivitas timulin. Kadar feritin yang tinggi juga memengaruhi kadar seng pada pasien talasemia. Suplementasi seng memperbaiki kadar seng yang berakibat pada perbaikan stres oksidatif dan respons imun pada pasien talasemia. Sari Pediatri 2016;18(2):157-63

Kata kunci: seng, respons imun, talasemia

\section{Zinc and Immune Responses in Thalassemia}

Teny Tjitra Sari

Infection is one of important morbidity and mortality in thalassemia patients. The mechanism infections are impaired immune response due to pathophysiology of thalassemia, iron overload, splenectomy, and zinc deficiency. Zinc plays important role in immune response associated with thymulin activity. High ferritin also influenced zinc level in thalassemia patients. Zinc supplementation results in increasing zinc level, improved oxidative stress and immune response in thalassemia patients. Sari Pediatri 2016;18(2):157-63

Keywords: zinc, immune response, thalassemia

Alamat korespondensi: DR. Dr. Teny Tjitra Sari, SpA(K). Departemen Ilmu Kesehatan Anak Fakultas Kedokteran Universitas Indonesia/RS Dr. Cipto Mangunkusumo, Jakarta. E-mail:t_tjitrasari@yahoo.com 
T alasemia adalah suatu penyakit anemia herediter akibat kelainan gen tunggal yang menyebabkan terjadinya defek pada produksi globin. ${ }^{1}$ Pembawa sifat talasemia di seluruh dunia diperkirakan sebanyak 1,5\% atau 80-90 juta orang. Thalassaemia International Federation (TIF) melaporkan di seluruh dunia sekitar 200.000 pasien talasemia terdaftar yang hidup dan mendapatkan terapi. ${ }^{2,3}$ Jumlah pasien yang terdaftar di Pusat Thalassaemia RS Dr. Cipto Mangunkusumo (RSCM), Jakarta, sampai bulan Desember 2015 adalah 1950 pasien. Jumlah pasien ini merupakan sepertiga dari total pasien talasemia di seluruh Indonesia. ${ }^{4}$

Infeksi merupakan penyebab penting morbiditas dan mortalitas pasien talasemia di seluruh dunia., ${ }^{5,6,7}$ Mekanisme yang berperan pada kerentanan pasien talasemia terhadap infeksi adalah respons imun pasien talasemia yang berbeda dari normal., ${ }^{6,9}$ Perbedaan tersebut akibat patofisiologi penyakit talasemia, ${ }^{8,9}$ kelebihan besi (iron overload), splenektomi, ${ }^{6,8,9}$ dan defisiensi seng. ${ }^{6}$

\section{Respons imun pada talasemia}

Anak yang menderita talasemia menunjukkan gangguan imunologik, baik imunitas innate maupun spesifik. Pada talasemia terjadi perubahan imunitas innate berupa penurunan C3 dan C4, defek kemotaksis, fagositosis neutrofil dan makrofag, defek fungsi sel NK, dan penurunan jumlah sel NK yang dihubungkan dengan transfusi darah. ${ }^{6,8}$ Namun, penelitian Shaiegan $\mathrm{dkk}^{10}$ dan Pattanapanyasat $\mathrm{dkk}^{11}$ melaporkan tidak ada perbedaan fagositosis neutrofil pasien talasemia dibanding normal. Perubahan imunitas selular berupa peningkatan jumlah dan aktivitas sel supresor CD8+, penurunan rasio $\mathrm{CD} 4+/ \mathrm{CD} 8+$, penurunan proliferasi sel $T$, peningkatan aktifasi sel $T$ yang juga dihubungkan dengan transfusi darah. ${ }^{5,6}$

Stimulasi aloantigenik akibat transfusi berulang dan kadar besi yang tinggi pada pasien talasemia menyebabkan keadaan inflamasi. Keadaan inflamasi terus menerus terjadi pada pasien talasemia pascasplenektomi dan non-splenektomi ditunjukkan dengan tingginya kadar interleukin (IL)-6, IL-8, IL-1 $\beta$, tumor necrosis factor (TNF)- $\alpha$, interferon (IFN) $-\gamma^{12,13}$ Keadaan inflamasi menurun setelah pemberian terapi deferipron selama 3-12 bulan, diperlihatkan dengan kadar TNF- $\alpha$, IL-2 dan IL-
2sR $\alpha$ yang kembali normal. ${ }^{14}$ Penelitian Gharagozloo $\mathrm{dkk}^{15}$ melaporkan kadar IFN- $\gamma$ dan IL-2 menurun pada pasien talasemia, memperlihatkan keadaan imunosupresif pada pasien dengan kelebihan besi. Selain itu, penelitian yang sama juga melaporkan kadar TNF- $\alpha$ lebih tinggi pada pasien talasemia pasca-splenektomi dan jumlah limfosit pasien talasemia lebih tinggi dibanding normal. ${ }^{15}$ Kadar IL-8 berhubungan dengan kadar feritin $(r=0,694$; $\mathrm{p}<0,05)$ dan jumlah transfusi $(\mathrm{r}=0,64 ; \mathrm{p}<0,05)$, sedangkan IL-6 tidak berhubungan dengan parameter klinis, hematologik atau biokimia. Sitokin tersebut meningkatkan sintesis feritin dan ambilan besi serum di hati. ${ }^{13}$ Penelitian yang dilakukan oleh Dore $\mathrm{dkk}^{16}$ melaporkan bahwa tingginya kadar IL-8 pada pasien talasemia dibandingkan kelompok kontrol kemungkinan disebabkan hiperaktif makrofag akibat hemolisis kronik dan stimulasi antigen akibat transfusi kronik. Interleukin-8 (IL-8) merupakan sitokin yang diproduksi oleh sel mononuklear, sel endotel, dan fibroblas, yang merupakan protein chemoattractant untuk neutrofil yang menstimulasi kemotaksis dan degranulasi, tetapi juga mungkin mempunyai fungsi kompleks dalam regulasi proses inflamasi. ${ }^{16}$

Peran patofisiologi penyakit talasemia sangat memengaruhi respons imun pada pasien talasemia. Eritropoietik inefektif dan hemolisis menyebabkan monosit/makrofag menjadi hiperplasia dan hiperaktif memfagositosis prekursor eritrosit yang rusak dan juga eritrosit matur. ${ }^{9}$ Anemia yang berat pada pasien talasemia, juga merupakan faktor risiko terjadinya infeksi. ${ }^{17}$ Pemberian transfusi darah berulang berhubungan dengan stimulasi aloantigenik terus menerus dan juga berhubungan dengan hemolisis autoimun. Terjadi perubahan limfosit $\mathrm{T}$ dan $\mathrm{B}$ dan modifikasi fungsi monosit dan makrofag, peningkatan aktivasi limfosit T dan menurunnya jumlah sel NK. ${ }^{6}$ Multi transfusi merupakan penyebab perubahan defisiensi imun parsial pada pasien talasemia yang terlihat lebih jelas pada pasien splenektomi. Kadar transforming growth factor (TGF)- $\beta 1$ lebih tinggi dan IL-2 lebih rendah pada pasien splenektomi. ${ }^{18}$

Kelebihan besi merupakan penyebab utama terjadinya kelainan imunitas pada pasien talasemia. Besi penting dalam meregulasi ekspresi marker sel limfosit $\mathrm{T}$ di permukaan, memengaruhi ekspansi subset sel limfosit $T$ dan fungsi sel imun, dapat didemonstrasikan secara in vivo dan in vitro. Ketidakmampuan limfosit dalam mengeluarkan sisa feritin dapat menjelas- 
kan abnormalitas sistem imun. Efek kelebihan besi meliputi terjadinya hambatan aktivitas IFN- $\gamma$ dan hilangnya kemampuan makrofag untuk membunuh patogen intrasel, penurunan fagositosis monosit/ makrofag dan neutrofil, gangguan aktivitas sel NK, perubahan subset limfosit $\mathrm{T}$ (menambah jumlah dan aktivitas limfosit $\mathrm{T}$ supresor (CD8+), menurunkan kapasitas proliferatif, jumlah dan aktivitas limfosit T helper (CD4+) dengan menurunnya rasio CD4+/ $\mathrm{CD} 8+$, mengganggu generasi limfosit $\mathrm{T}$ sitotoksik dan mengubah generasi limfosit $\mathrm{T}$ sitotoksik) gangguan sekresi imunoglobulin dan supresi fungsi sistem komplemen (tipe klasik atau alternatif). ${ }^{6,19,20}$ Terdapat hubungan antara rendahnya jumlah limfosit CD8+, kerusakan hati akibat $\mathrm{HCV}$ positif, dan parahnya kelebihan besi pada pasien talasemia. ${ }^{20}$

Kelebihan besi menyebabkan perubahan toksik pada jaringan melalui pelepasan radikal bebas dan menginduksi stres oksidatif. Antioksidan, seperti vitamin $\mathrm{E}$, vitamin $\mathrm{C}$, dan selenium dapat memodulasi kerusakan oksidatif. ${ }^{19}$ Atasever dkk ${ }^{19}$ melaporkan bahwa suplemen vitamin $\mathrm{C}$ dan selenium dibutuhkan untuk meningkatkan aktivitas sel NK. Faktor risiko utama lain pasien talasemia yang mengalami infeksi berat adalah terlambatnya menggunakan kelasi besi. ${ }^{21}$

Defisiensi imun parsial lebih terlihat pada pasien yang dilakukan splenektomi. ${ }^{18}$ Limpa berperan penting dalam respons imun karena limpa merupakan sumber penting limfosit imunokompeten. ${ }^{9}$ Limpa dan kelenjar getah bening merupakan tempat sel dendritik mempresentasikan antigen yang ditangkap di bagian lain tubuh ke sel $\mathrm{T}$ yang memacunya untuk proliferasi dan diferensiasi limfosit. ${ }^{22}$ Secara umum, limpa berfungsi untuk memfiltrasi antigen dan mikroorganisme dan juga berfungsi dalam proses sintesis antibodi dan komplemen. ${ }^{23}$ Pada keadaan splenektomi, produksi antibodi terhadap antigen baru yang dimediasi CD4+ menjadi terganggu. ${ }^{29}$ Keadaan inflamasi makin buruk setelah dilakukan splenektomi, yang terlihat dengan kadar $C$-reactive protein (CRP) yang lebih tinggi pada pasien talasemia pasca-splenektomi dibanding nonsplenektomi. ${ }^{12}$ Ahluwai $\mathrm{dkk}^{24}$ memperlihatkan tidak ada perbedaan bermakna kadar imunoglobulin dan fungsi neutrofil antara kelompok pasca-splenektomi dan non-splenektomi. Kelompok pasca-splenektomi mempunyai jumlah limfosit yang lebih tinggi dan rasio $\mathrm{CD} 4+/ \mathrm{CD} 8+$ lebih rendah. ${ }^{24}$

Pada pasien talasemia terjadi perubahan imunitas humoral berupa peningkatan jumlah dan aktivitas limfosit B serta peningkatan imunoglobulin ( $\mathrm{IgG}$, IgM dan IgA). ${ }^{6,25}$ Namun, penelitian Kiani-amin dkk ${ }^{26}$ melaporkan tidak ada perbedaan kadar IgG dan IgM pada kedua kelompok (pasca-splenektomi dan nonsplenektomi) dan semua kelompok umur. Rerata IgA serum meningkat pada kelompok non-splenektomi usia $<5$ tahun dan pada kelompok pasien pascasplenektomi usia $>20$ tahun, sedangkan kelompok usia lain kadar IgA normal. ${ }^{26}$ Penelitian Vergin $\mathrm{dkk}^{27}$ juga melaporkan tidak ada perbedaan kadar imunoglobulin pada pasien talasemia- $\beta$ pasca-splenektomi dan nonsplenektomi. Hasil penelitian imunitas humoral pada pasien talasemia sangat bervariasi karena perbedaan metode penelitian.

\section{Seng dan respons imun}

Terdapat beberapa hipotesis yang menjelaskan peran seng dalam imunitas. Hipotesis pertama adalah seng berperan penting pada aktivitas 300 enzim untuk fungsi polimerase DNA, thymidine kinase dan polimerase RNA bergantung DNA. Hipotesis kedua yaitu seng berperan penting pada aktivitas biologis terhadap timulin. Hipotesis ketiga adalah seng mempunyai peran penting dalam stabilisasi membran pada tingkat sitoskeletal dan hipotesis keempat yaitu seng merupakan pengatur intrasel dalam proses apoptosis limfosit baik in vitro maupun in vivo. ${ }^{28}$

Seng merupakan zat yang esensial bagi sistem imun dan diperlukan untuk menginduksi aktivitas biologis terhadap timulin. ${ }^{8}$ Timulin merupakan suatu hormon peptida yang dihasilkan oleh sel timus subkapsular dan medular. Seng diperlukan untuk menginduksi aktivitas biologis timulin. ${ }^{29,30}$ Timulin berfungsi mengatur diferensiasi sel $\mathrm{T}$ matur di timus dan fungsi sel $\mathrm{T}$ matur di perifer, memodulasi pelepasan sitokin oleh sel mononukleus di perifer, dan menginduksi proliferasi CD8+. ${ }^{30}$ Defisiensi seng mengakibatkan atrofi timus dan jaringan limfoid, gangguan pembentukan limfosit T sitotoksik, penurunan aktivitas sel NK, gangguan reaktivitas uji kulit tipe lambat, penurunan respons proliferatif limfosit terhadap mitogen, dan penurunan selektif pada sel CD $4+.{ }^{29,30}$ Menurut Dardenne dkk, ${ }^{28}$ defisiensi seng secara ringan dapat menyebabkan ketidakseimbangan fungsi sel Th1 dan Th2, sedangkan produksi dari IL-4, IL-6 dan IL-10 tidak terpengaruh. 


\section{Seng dan respons imun pada talassemia}

Penelitian Consolini $\mathrm{dkk}^{31}$ melaporkan aktivitas timulin menurun secara bermakna pada pasien talasemia dibanding normal, tanpa berkorelasi dengan infeksi kronik atau komplikasi endokrin. Kadar timulin yang rendah pada pasien talasemia tidak disebabkan oleh kegagalan timus menyintesis dan menyekresi hormon timus, tetapi hal ini akibat defek saturasi seng. Hal ini juga didukung oleh rendahnya kadar seng yang berhubungan dengan rendahnya kadar timulin dan berhubungan dengan peningkatan bentuk aktif hormon tersebut setelah ditambahkan seng secara in vitro. ${ }^{8}$

Pada keadaan defisiensi seng, jumlah neutrofil dan fagositosis menurun, proliferasi limfosit $T$ menurun, limfosit T CD4+ juga terpengaruh dan berakibat pada ketidakseimbangan fungsi Th1 dan Th2. Selain itu, terjadi penurunan produk sel Th1 seperti IFN- $\gamma$ dan IL-2, sedangkan produk Th2 yaitu IL-4, IL-6 dan IL10 tetap tidak berubah. Produksi Th1 akan terkoreksi bila diberikan suplementasi seng. Suplementasi seng juga menyebabkan meningkatnya jumlah limfosit $\mathrm{T}$ dan meningkatkan produksi IL-2. Respons limfosit terhadap stimulasi PHA seperti aktivitas sel NK meningkat secara bermakna dibanding kelompok plasebo. Jumlah CD4+ dan limfosit T sitotoksik meningkat secara bermakna dan meningkatkan respons imun selular. ${ }^{30}$

Kelainan morfologik sel darah merah pada talasemia membuat sel rentan terhadap stres oksidatif, sedangkan kelebihan besi dan rantai- $\alpha$ pada pasien talasemia menimbulkan stres oksidatif. Stres oksidatif akan menginduksi enzim antioksidan termasuk super oxide dismutase (SOD) dan gluthatione peroxidase (GPX). Seng merupakan salah satu unsur di dalamnya.

Di Pusat Thalassaemia RSCM didapatkan 65 dari 67 pasien talasemia mempunyai asupan seng yang rendah dan pada seluruh subjek penelitian terjadi defisiensi seng $(<75 \mu \mathrm{g} / \mathrm{dL}){ }^{32}$ Pada penelitian Arijanty $\mathrm{dkk}^{32}$ didapatkan kadar seng serum pasien talasemia tidak berkaitan dengan asupan seng dalam makanan, tetapi lebih banyak dipengaruhi oleh kadar feritin ( $\mathrm{r}=$ $-0,282 ; \mathrm{p}=0,021)$ berupa persamaan kadar seng serum $(\mu \mathrm{g} / \mathrm{dL})=47,93+(-0,01)$ feritin plasma $(\mathrm{ng} / \mathrm{mL})$. Tidak ada hubungan antara berat badan dengan kadar seng serum dan asupan seng dalam makanan dengan status gizi $(\mathrm{p}=0,21)$. Pada proses metabolisme, seng diangkut oleh albumin dan transferin ke dalam aliran darah kemudian disimpan di dalam hati dalam bentuk metalotionein sampai tubuh membutuhkannya. Jika terdapat banyak metalotionein di dalam tubuh maka absorpsi seng pun akan berkurang. Darah membawa ikatan seng-albumin ke jaringan tubuh yang lain, sebagian hilang melalui urin, kulit, darah, dan mani. Selanjutnya, seng juga dibawa ke pankreas untuk membuat enzim pencernaan. ${ }^{32}$

Selain itu, diet tertentu pada pasien talasemia menyebabkan pasien mengurangi jumlah konsumsi besi dalam diet dan menurunnya kadar seng pada asupan diet. ${ }^{33}$ Sumber seng nabati adalah sayuran dan biji-bjian atau gandum. Sumber seng yang berasal dari hewan, seperti daging, makanan laut, serta produk susu, lebih mudah diabsorpsi karena protein hewani tidak dihambat oleh asam fitat. Kadar feritin yang tinggi pada subjek talasemia dapat menghambat absorpsi seng karena besi dan seng bersaing untuk berikatan dengan transferin setelah diabsorpsi pada mukosa jejunum dan ileum. Sebagian seng menggunakan transferin sebagai alat transpor yang juga merupakan alat transpor besi. Bila perbandingan antara besi dengan seng lebih dari $2: 1$, transferin yang tersedia untuk seng berkurang, sehingga menghambat absorpsi seng. ${ }^{32}$

Penelitian Tienboon ${ }^{34}$ di Thailand memberikan suplementasi nutrisi berupa susu selama 1 bulan yang di antaranya berisi seng pada pasien anak dengan talasemia mayor non-splenektomi, memperlihatkan hasil peningkatan respons proliferatif limfosit dan persentase CD4+ serta menurunnya CD8+. Dosis suplementasi seng yang diberikan adalah $1,5 \mathrm{mg} / \mathrm{kg} /$ hari untuk memenuhi 3 kali angka kecukupan gizi (AKG).$^{34}$ Penelitian Rashidi $\mathrm{dkk}^{33}$ memberikan seng pada pasien talasemia dewasa dengan dosis $50 \mathrm{mg} /$ hari bersamaan dengan vitamin $\mathrm{E}$ dosis $400 \mathrm{mg} / \mathrm{hari}$ memperlihatkan peningkatan bermakna kadar seng dan vitamin E. Selain itu, terjadi perbaikan keadaan stres oksidatif yang diperlihatkan dengan menurunnya kadar enzim antioksidan $(\mathrm{p}<0,029) .{ }^{33}$

Pemberian kelasi besi juga memengaruhi kadar seng pada pasien talasemia. Penelitian Bartakke ${ }^{35}$ melaporkan sekresi seng di urin lebih besar pada pasien talasemia yang menggunakan deferipron sebagai kelasi besi, sedangkan Cappellini $\mathrm{dkk}^{36}$ melaporkan tidak ada perbedaan kadar seng pada pasien yang mendapatkan deferasiroks dan desferioksamin. Kadar seng pada pemberian terapi kombinasi deferipron dan desferioksamin memberikan hasil yang bervariasi. 
Origa $\mathrm{dkk}^{37}$ melaporkan defisiensi seng terjadi pada $40 \%$ kasus, sedangkan lainnya tidak mendapatkan perubahan kadar seng. ${ }^{38,39}$ Pemberian suplementasi seng sebanyak $200 \mathrm{mg} 2$ kali seminggu memperbaiki kadar seng yang terjadi saat pemberian kelasi besi. ${ }^{37}$ Gangguan respons imun talasemia dan pengaruh pemberian seng dapat dilihat pada Gambar. 1.

\section{Kesimpulan}

Seng merupakan zat yang esensial bagi sistem imun. Hal ini dihubungkan dengan gangguan aktivitas timulin yang berakibat pada, ketidakseimbangan fungsi Th1 dan Th2. Kadar feritin yang tinggi juga memengaruhi kadar seng pada pasien talasemia. Suplementasi seng memperbaiki kadar seng yang berakibat pada perbaikan stres oksidatif dan respons imun pada pasien talasemia.

\section{Daftar pustaka}

1. Rund D, Rachmilewitz E. $\beta$-thalassemia. N Engl J Med 2005;353:1135-46.

2. Eleftheriou A. About thalassemia. Cyprus: Thalassemia International Federation; 2007.h.38-76.

3. Taher A, Vichinsky E, Musallam K, Cappellini MD, Viprakasit V. Guidelines for the management of non transfusion dependent thalassaemia (NTDT). Cyprus: Thalassemia International Federation; 2013.h.2.

4. Data Register Pusat Thalassaemia RSCM Jakarta, tidak dipublikasikan.

5. Ezer Ü, Gülderen F, çulha VK, Akgül N, Gürbüz Ö. Immunological status of thalassemia syndrome. Pediatr Hematol Oncol 2002;19:51-8.

6. Vento S, Cainelli F, Cesario F. Infections and thalassemia. Lancet Infect Dis 2006;6:226-33.

7. Chern JPS, Su S, Lin KH, Chang SH, Lu MY, Jou ST,

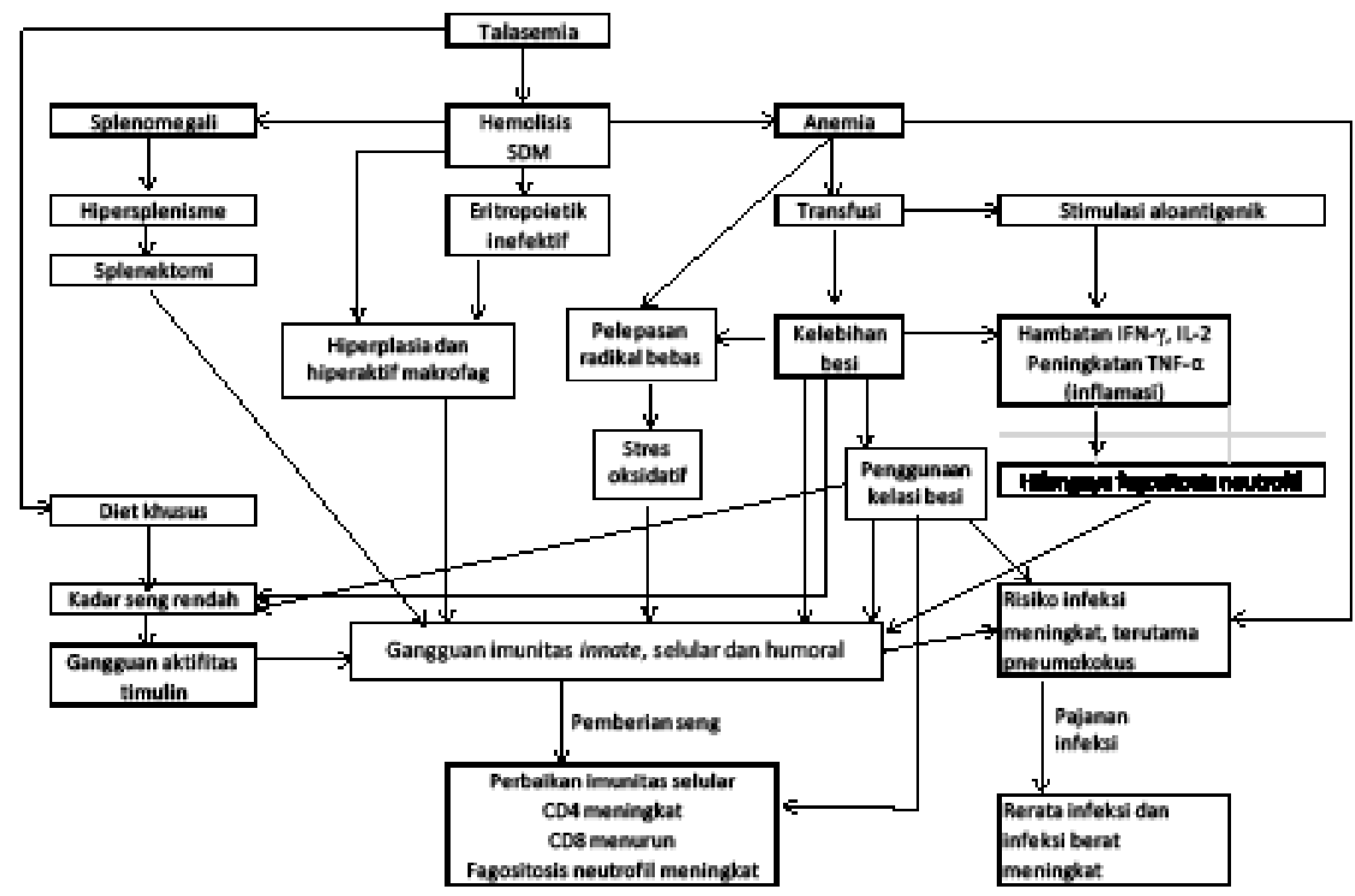

Gambar 1. Respons imun pada talasemia 
Teny Tjitra Sari: Seng dan respons imun pada talasemia

dkk. Survival, mortality and complications in patients with $\beta$-thalassmia major in Northern Taiwan. Pediatr Blood Cancer 2007;48:550-4.

8. Wiener E. Impaired phagocyte antibacterial effector functions in $\beta$-thalassemia: a likely factor in the increased susceptibility to bacterial infections. Hematology 2003;8:35-40.

9. Ricerca BM, Di Girolamo A, Rund D. Infections in thalassemia and hemoglobinopathies: focus on therapyrelated complications. Mediterr J Hematol Infect Dis. 2009;1:e2009028. Diunduh tanggal 15 Februari 2012. Didapat dari: www.mjhid.org/article/view/5229.

10. Shaiegan M, Abdee J, Zaman-Vaziree M, Khajehian A. Comparison of neutrophil function in patients with thalassemia major and healthy controls. Arch Iranian Med 2002;5:175-8.

11. Pattanapanyasat K, Sukapirom K, Tachavanich K, Kaewmoon S. Flow cytometric quantitation of opsonophagocytosis and intracellular killing of Candida albicans using a whole blood microassay. Cytometry 2007;71A:1027-33.

12. Gangemi S, Merendino RA, Meo A, Minciullo PL, Briuglia S, Merlino MV, dkk. Serum levels of interleukin-18 in splenectomized and nonsplenectomized thalassemic patients: preliminary considerations. Acta Haematol 2003;110:45-7.

13. Öztürk O, Yaylim I, Aydin M, Yilmaz H, Ağaçhan B, Demiralp E, dkk. Increased plasma levels of interleukin-6 and interleukin-8 in $\beta$-thalassemia major. Haematologia 2001;31:237-44.

14. Cunningham-Rundles S, Giardina PJ, Grady RW, Califano C, McKenzie P, De Sousa M. Effect of transfusional iron overload on immune response. JID 2000;182:S115-21.

15. Gharagozloo M, Karimi M, Amirghofran Z. Doublefaced cell-mediated immunity in $\beta$-thalassemia major: stimulated phenotype versus suppressed activity. Ann Hematol 2009;88:21-7.

16. Dore F, Bonfigli S, Pardini S, Longinotti M. Serum interleukin-8 levels in thalassemia intermedia. Haematologica 1995;80:431-3.

17. Wanachiwanawin W. Infection in E- $\beta$ thalassemia. J Pediatr Hematol Oncol 2000;22:581-7.

18. Mosthtaghi-Kashanian GR, Gholamhoseinian A, Hoseinmoghadam A, Rajabalian S. Splenectomy changes the pattern of cytokine production in $\beta$-thalassemic patients. Cytokine 2006;35:253-7.

19. Atasever B, Kuruca SE, Karakas Z, Agaoglu L. In vitro modulation of cellular immunity with antioxidants in patients with thalassemia major. Blood (ASH Annual Meeting Abstracts). 2004;104:Abstract 3775.

20. Walker EM, Walker SM. Effects of iron overload on the immune system. Ann Clin Lab Sci 2000;30:354-65.

21. Wang SC, Lin KH, Chern JPS, Lu MY, Jou ST, Lin DT, dkk. Severe bacterial infection in transfusiondependent patients with thalassemia major. Clin Infect Dis 2003;37:984-8.

22. Baratawidjaja KG, Rengganis I. Imunologi dasar. Edisi ke-11. Jakarta: Badan Penerbit Fakultas Kedokteran Universitas Indonesia; 2014.h.41-745.

23. Sakran W, Levin C, Kenes Y, Colodner R, Koren A. Clinical spectrum of serious bacterial infections among splenectomised patients with hemoglobinopathies in Israel: a 37-year follow-up study. Infection 2012;40:35-9.

24. Ahluwalia J, Datta U, Marwaha RK, Sehgal S. Immune functions in splenectomized thalassaemic children. Indian J Pediatr 2000;67:871-6.

25. Cunningham-Rundles S, Giardina PJ, Grady RW, Califano C, McKenzie P, De Sousa M. Effect of transfusional iron overload on immune response. JID 2000;182:S115-21.

26. Kiani-amin M, Mohammadmehdi D, Parviz A, Shima M, Nima R. Serum immunoglobulin levels in splenectomized and non-splenectomized patients with major beta-thalassemia. Iranian J Pediatr 2011;21:95-8.

27. Vergin C, Kutukculer N, Cetingul N, Nisli G, Caglayan S, Oztop S. Serum immuno-globulins, IgG subclasses, isohemagglutinins and complement-3 levels in patients with thalassemia major. Indian J Pediatr 1997;64:215-9.

28. Dardenne M. Zinc and immune function. Eur J Clin Nutr 2002;56:S20-3.

29. Fraker PJ, King LE, Laakko T, Vollmer TL. The dynamic link between the integrity of the immune system and zinc status. J Nutr 2000;130:S1399-1406.

30. Ibs KH, Rink L. Zinc-altered immune function. J Nutr 2003;133:S1452-6.

31. Consolini R, Calleri A, Legitimo A, Massei F. Immunological evaluation of patients with beta-thalassemia major. Acta Haematol 2001;105:7-12.

32. Arijanty L, Nasar SS, Madiyono B, Gatot D. Relationships between plasma zinc and ferritin with nutritional status in thalassemic children. Paediatr Indones 2006;46:220-4.

33. Rashidi $M$, Aboomardani M, Rafraf M, Arefhosseini SR, Keshtkar A, Joshaghani H. Effects of vitamin E and zinc supplementation on antioxidants in beta thalassemia major patients. Iran J Pediatr 2011;21:8-14.

34. Tienboon P. Effect of nutrition support on immunity 
in paediatric patients with beta-thalassaemia major. Asia Pacific J Clin Nutr 2003;12:61-5.

35. Bartakke S, Bavdekar SB, Kondurkar P, Muranjan MN, Manglani MV, Sharma R. Effect of deferiprone on urinary zinc excretion in multiply transfused children with thalassemia major. Indian Pediatr 2005;42:150-4.

36. Cappellini MD, Cohen A, Piga A, Bejaoui M, Perrotta S, Agaogiu L, dkk. A phase 3 study of deferasirox (ICL670), a once-daily iron chelator in patients with $\beta$-thalassemia. Blood 2006;107:3455-62.

37. Origa R, Bina P, Agus A, Crobu G, Defraia E, Dessi C, dkk. Combined therapy with deferiprone and desferrioxamine in thalassemia major. Haematologica 2005;90:1309-14.

38. Galanello R, Kattamis A, Piga A, Fischer R, Leoni G, Ladis $\mathrm{V}$, dkk. A prospective randomized controlled trial on the safety and efficacy of alternating deferoxamine and deferiprone in the treatment of iron overload in patients with thalassemia. Haematologica 2006;91:1241-3.

39. Tanner MA, Galanello R, Dessi C, Smith GC, Westwood MA, Agus A, dkk. A randomized, placebo-controlled, double-blind trial of the effect of combined therapy with deferoxamine and deferiprone on myocardial iron in thalassemia major using cardiovascular magnetic resonance. Circulation 2007;115:1876-84. 